\title{
Morphological Characteristics and Allometric Relationships of Shoot in Two Undergrowth Plants: Polygonatum odoratum and Polygonatum multiflorum
}

\author{
Mirela Tulik ${ }^{1, *}$, Jerzy Karczewski ${ }^{2}$, Natalia Szeliga ${ }^{3}$, Joanna Jura-Morawiec 4 \\ and Ingeborga Jarzyna ${ }^{5}$ \\ 1 Department of Forest Botany, Warsaw University of Life Sciences-SGGW, 02-776 Warsaw, Poland \\ 2 Department of Biophysics and Plant Morphogenesis, University of Silesia, 40-032 Katowice, Poland; \\ jerzy.karczewski@us.edu.pl \\ 3 Lezajsk Forest District, 37-300 Lezajsk, Poland; natalia.szeliga.2017@gmail.com \\ 4 Polish Academy of Sciences Botanical Garden-Centre for Biological Diversity Conservation in Powsin, \\ 02-973 Warsaw, Poland; j.jura@gazeta.pl \\ 5 Faculty of Biology, Biological and Chemical Research Centre, University of Warsaw, 02-089 Warsaw, Poland; \\ i.jarzyna@uw.edu.pl \\ * Correspondence: mirela.tulik@wl.sggw.pl; Tel.: +48-22-593-8032
}

Received: 16 November 2018; Accepted: 17 December 2018; Published: 19 December 2018

\begin{abstract}
The main purpose of this investigation was to describe the spatial arrangement of shoot tissues, as seen in transverse section, and allometric relationships in two contrasting species of Polygonatum i.e., Polygonatum odoratum which commonly grows in mixed pine-oak forest with shoots rectangular in shape, and Polygonatum multiflorum found in oak-hornbeam forest with cylindrical shoots. The mass and length of the aerial shoots of each individual plant were measured. The shoot regions of each plant were then categorized as basal (b), central (c) or apical (a). Transverse sections of these shoot regions were subsequently cut, and the following parameters were measured: (1) Diameter of shoots, (2) thickness of the outer and inner zones of parenchyma and (3) thickness of the sclerenchyma zone. Additional allometric relationships between the various measurements were computed and determined as Pearson's correlation coefficients $(r)$. Both species of Polygonatum differed significantly with respect to the length, diameter and thickness of the outer zone of parenchyma. Shoots of P. multiflorum were taller but narrower than those of P. odoratum, which had a significantly wider zone of outer parenchyma. Allometric relationships were stronger for P. multiflorum, and for both species, they were generally stronger in the basal part of the shoot. We conclude that in P. multiflorum, the strong correlation between the diameter and length of the shoot seems to be important to the growth in shaded environments.
\end{abstract}

Keywords: allometry; anatomy; Polygonatum odoratum; Polygonatum multiflorum; shape; shoot

\section{Introduction}

Spatial organization of the plant body is defined as plant architecture subject to genetic and environmental control [1]. It is widely believed that the purpose of the mechanical integrity of the shoot is to ensure the reproductive success and survival of the plant [2]. Such mechanical integrity, and the peripheral location (or peripheral concentration in the case of monocots) of vascular bundles and mechanical supporting tissues such as collenchyma and sclerenchyma also enable the plant to resist and respond to physical forces such as wind and are exacerbated by the weight of the plant itself [3]. Crook et al. [4] demonstrated that plants occupying different habitats are able to modify their structural investment so as to maintain a "constant factor of safety" against mechanical failure. 
As a consequence, plants that grow in exposed sites differ from those occupying more sheltered environments in terms of their morphology and anatomy [5].

In a forest, light is one of the main factors affecting species diversity and coexistence of plants [6,7]. It influences the abundance [8] and composition [9] of species in the understory. The plants growing on the forest floor obtain only $0.5 \%-5 \%$ of incident light [10]; in tropical rainforests less than $1 \%$ [11] and less than $2 \%-5 \%$ in moderately humid deciduous forests [12].

We examined two species of Polygonatum, growing on the forest floor namely Polygonatum odoratum (Mill.) Druce and Polygonatum multiflorum (L.) All, both members of the monocotyledonous family Asparagaceae (APG III 2009). These differ from each other in several ways, including the number of flowers located in leaf axils, the size and shape of the shoot, and the habitats that they occupy. One of the most distinct differences between their habitats is the amount of light reaching the forest floor [13]. P. odoratum is native to Europe, Asia, and Northern Africa (http:/ / e-monocot.org). It prefers semi-shade and a moderately exposed habitat, where it grows to a height of $\sim 65 \mathrm{~cm}$. Its white, tubular flowers (one, rarely two per axil) hang singly from the underside of the shoot, which is square to rectangular in transverse section. By contrast, $P$. multiflorum can grow to a height of $80 \mathrm{~cm}$ in deciduous European or Asian forests (beech, oak and hornbeam). Its tubular flowers are also white (usually 3-5 per leaf axils) and also hang from beneath the shoot which, unlike that of P. odoratum, is cylindrical in shape and round in transverse section.

Since mechanical design, whether it be at the cellular level or at the level of whole-plant architecture, appears to be fundamental to survival, the main purpose of this investigation was to describe the spatial arrangement of shoot tissues, as seen in transverse section, and allometric relationships in two contrasting species of Polygonatum.

\section{Materials and Methods}

Shoots of the two species used for our study (P. multiflorum and P. odoratum) were collected in the late spring of 2015 and 2017. Fifteen flowering individuals of each species were collected for each of the two years of our study. Individuals of P. odoratum were found in mixed pine-oak forest Querco roboris-Pinetum (W. Mat.1981) J. Mat. 1988) whereas P. multiflorum grew in sub-continental oak-hornbeam forest (Tilio-Carpinetum Tracz. 1962). Plants of each species were cut at ground level, protected from desiccation, and brought to the laboratory, where they were subjected to investigations.

Shoot length (L) was subsequently measured and three shoot regions determined for each, namely: Basal (b), located close to the base of the shoot; central (c), located in the middle part of the shoot; and apical (a), located near the apex (Figure 1).

Hand-cut transverse sections were then obtained from each of these shoot regions for both species. The protocol using carrot and cork, as recommended by Gärtner and Schweingruber [14], was adopted for preparing sections using a sliding microtome (Microm HM 440, GMI Inc, Ramsey, MN, USA). For the detection of lignified cell walls, sections were stained with Alcian blue and Safranin [15] and some sections were also observed under UV (ultraviolet) light. Photomicrographs were achieved with the aid of an Olympus system consisting of a BX61 motorized microscope (Olympus, Tokyo, Japan) and Cell P image analysis software (version 3.4) coupled to a Color View digital camera (Olympus Soft Imaging System GmbH, Múnster, Germeny). Based on images taken from each region of the shoot for every individual, the following parameters were measured: (1) diameter of shoot (D); (2) thickness of mechanical tissue zone (sclerenchyma zone, Ws); (3) thickness of parenchyma tissue located externally to the mechanical tissue (hereafter referred to as outer parenchyma zone (Wp)); and (4) thickness of inner parenchyma zone ( $\mathrm{W} \mathrm{p}_{\mathrm{i}}$, calculated and expressed as the difference between the diameter and the sum of the thicknesses of outer parenchyma and sclerenchyma zones, as follows: $\left.W p_{i}=D-(W p+W s)\right)$. Measurements were performed at two points on the circumference of each section and the average measurements calculated. The accuracy of these measurements was $\pm 0.01 \mathrm{~mm}$. 


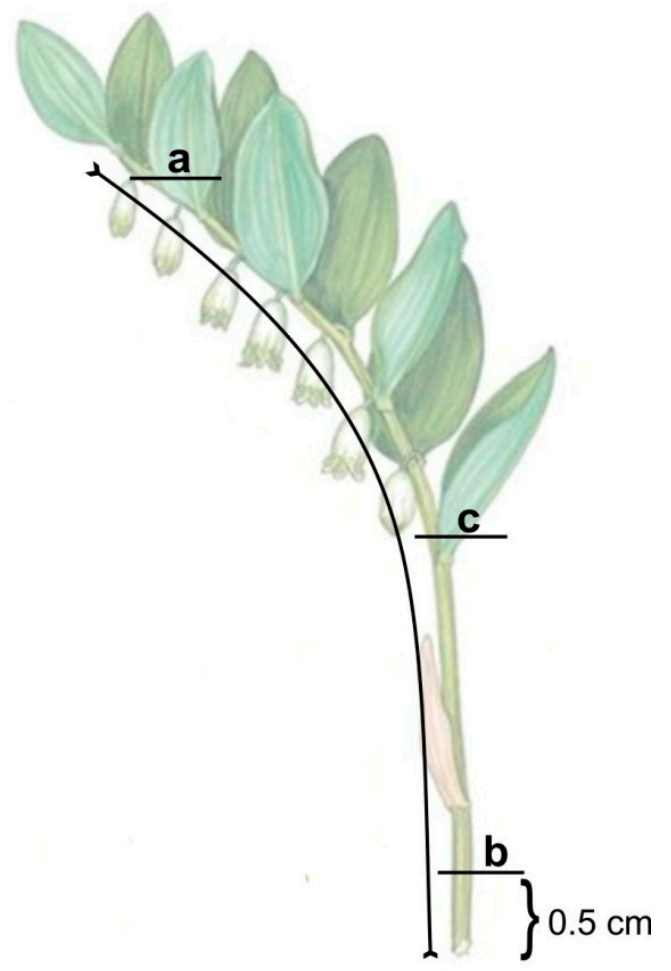

Figure 1. Location of three regions along the length of Polygonatum shoot categorized as basal (b), central (c) and apical (a). Region (b) was $0.5 \mathrm{~cm}$ above ground level.

In addition, we determined the mass $(\mathrm{M})$ of the entire aerial part of individual plants collected in 2017 and measured shoot length (L). Accuracy of the measurements was $\pm 0.01 \mathrm{~g}$ and $\pm 0.1 \mathrm{~mm}$, respectively. The allometric relationships between all measurements were characterized by allometric scaling laws of the form $\mathrm{Y}=\mathrm{cM}^{\mathrm{b}}$ ( $\mathrm{c}$-constant, $\mathrm{b}$-allometric scaling coefficient) and determined as Pearson's correlation coefficients $(r)$ on data transformed to a natural logarithm. A similar method was used by Niklas [5], Weiner and Thomas [16], and Poorter et al. [17].

Significance of difference between means was assessed by Student's t-test. Analyses were computed on Statistica software, version 13.

\section{Results}

\subsection{Morpho-Anatomical Analysis of Polygonatum Shoots}

Shoot anatomy of both investigated species demonstrated significant similarity, despite differences in the cross-sectional shape of the shoots (rectangular in P. odoratum and round in P. multiflorum; Figure $2 a, b$ ). The shoots of both species were comprised of epidermis, ground tissue and collateral vascular bundles. The ground tissue was represented by the outer parenchyma, sclerenchyma and inner parenchyma (core). The collateral, closed vascular bundles, were irregularly scattered throughout the ground tissue (Figure 2c-e). Towards the outer parenchyma, the bundles were smaller in size, whereas those near the centre of the shoot were larger. The vascular bundles, especially those located peripherally, were enclosed within a sclerotic sheath comprised of layers of sclerenchyma fibres. 

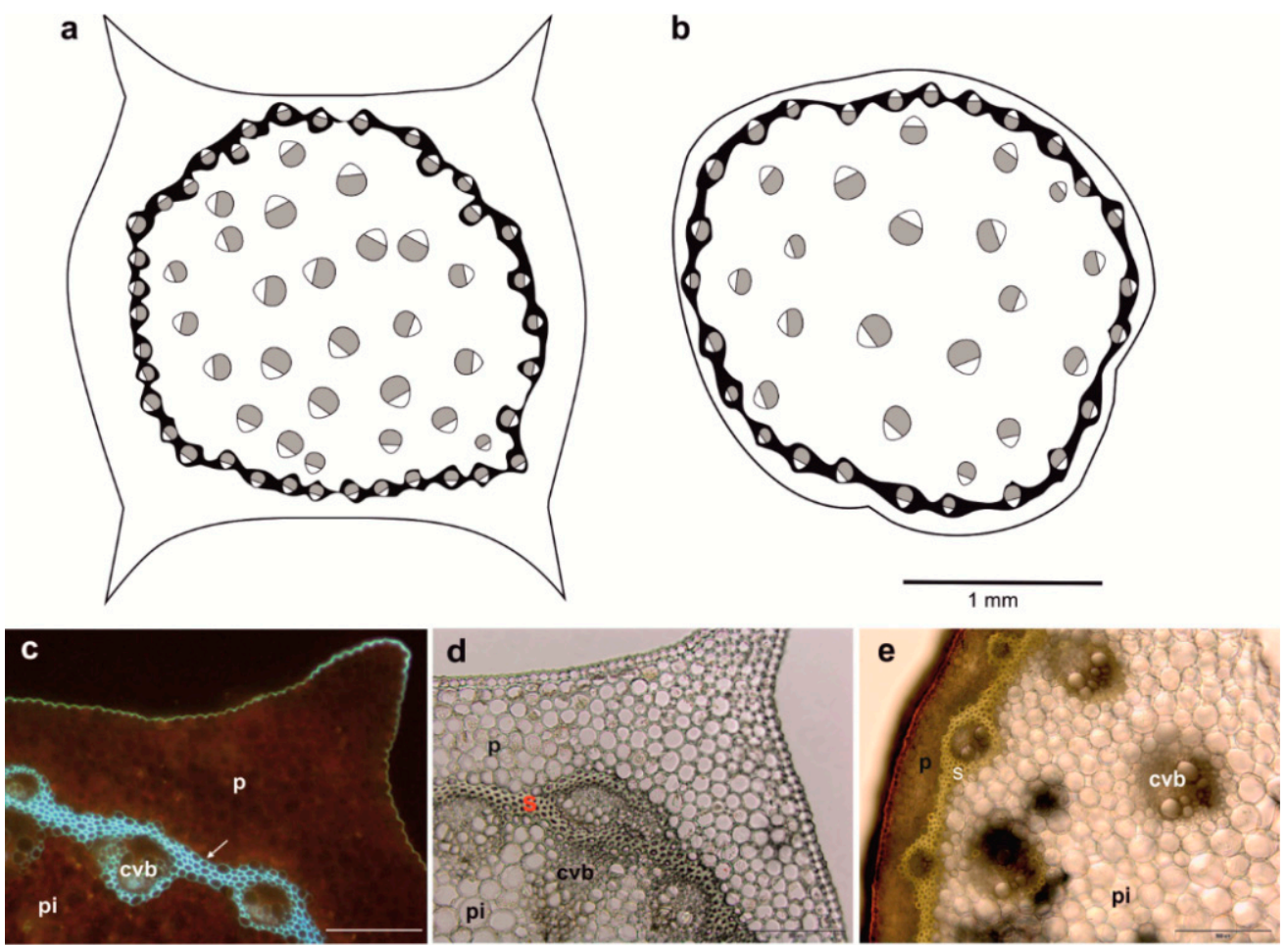

Figure 2. (a,b) Diagram showing shape of Polygonatum shoots as seen in transverse section; rectangular in P. odoratum (a) and circular in P. multiflorum (b). The sclerenchyma zone is marked black; the outer/inner parenchyma zone white. Vascular tissue is represented by scattered collateral bundles. (c-e) Photomicrographs of transverse sections of P. odoratum (c,d) and P. multiflorum (e) shoots. Scale bar $=200 \mu \mathrm{m}$. (c) —section viewed under UV light. Fluorescence of lignified cell walls of sclerenchyma cells is marked with arrow. $\mathrm{p}$-outer parenchyma zone; s-sclerenchyma zone; pi-inner parenchyma zone; cvb—collateral vascular bundle.

No significant difference were observed in the thickness of the sclerenchyma zone between the species at basal level. Nevertheless, plants varied significantly with respect to the thickness of the outer zone of parenchyma, regardless of region (Table 1 ).

Table 1. Values of Student's $t$-test for the mean thickness of the outer parenchyma zone for the three regions (basal, central, and apical) along the shoots of P. odoratum (P. o) and P. multiflorum (P. m).

\begin{tabular}{|c|c|c|c|c|}
\hline \multirow{2}{*}{$\begin{array}{c}\text { Variable at } \\
\text { Categorized Region }\end{array}$} & \multicolumn{2}{|c|}{ Mean } & \multirow{2}{*}{$t$-Value } & \multirow{2}{*}{$p$-Value } \\
\hline & P. o & P. $\mathrm{m}$ & & \\
\hline Basal & 0.1876 & 0.1047 & 8.6023 & 0.0000 \\
\hline Central & 0.1589 & 0.0930 & 7.3910 & 0.0000 \\
\hline Apical & 0.1555 & 0.0931 & 8.8375 & 0.0000 \\
\hline
\end{tabular}

In the basal region, the mean thickness of the outer parenchyma zone of $P$. odoratum reached $0.19 \mathrm{~mm}$, as compared with $0.10 \mathrm{~mm}$ in P. multiflorum (Figure 3). 


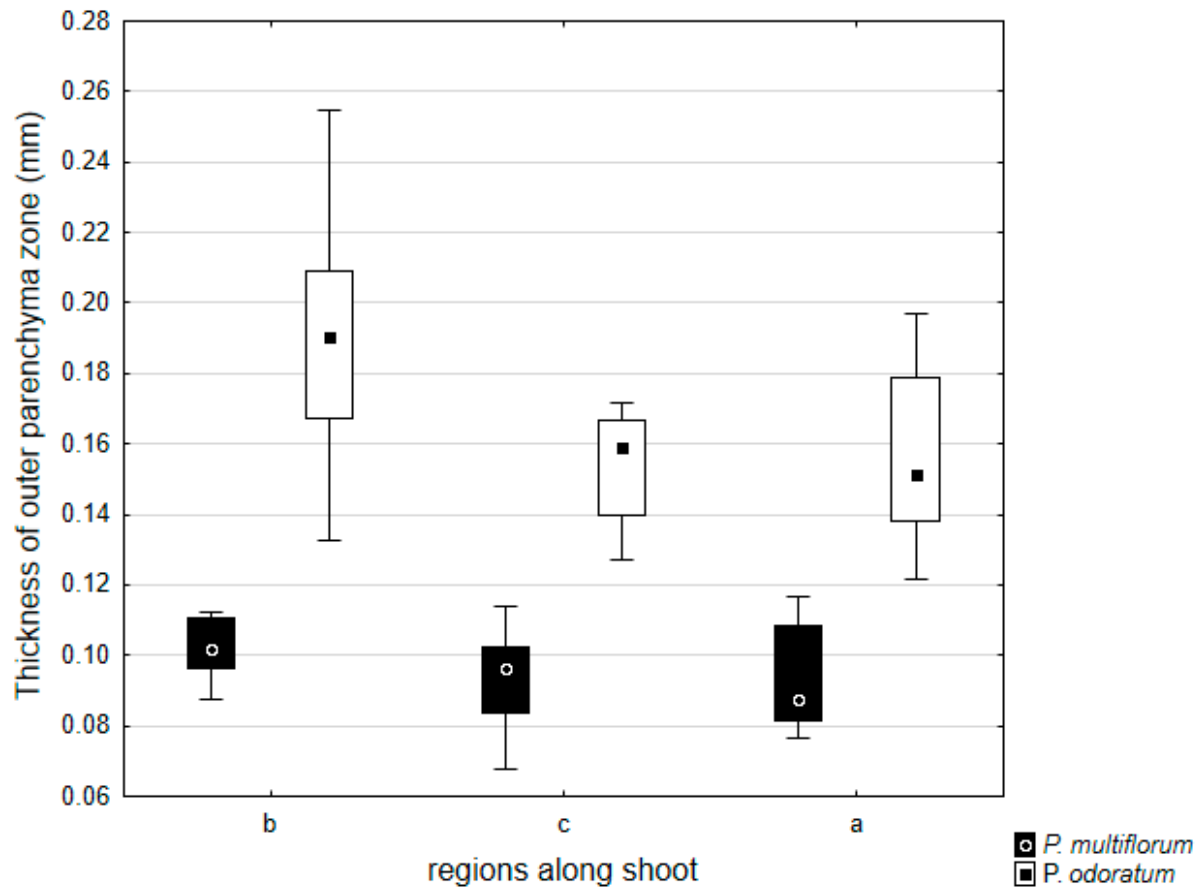

Figure 3. Thickness of outer parenchyma zone at basal (b), central (c) and apical (a) regions along shoot of both species.

For both species, the width of the outer parenchyma zone diminished along its length, although for P. multiflorum, the mean value at the central region was almost identical to that for the apical region. The mean thickness of the sclerenchyma zone in the basal region was similar: $0.055 \mathrm{~mm}$ for P. odoratum and $0.053 \mathrm{~mm}$ for P. multiflorum. In both species, the diameter of shoot and thickness of the sclerenchyma zone diminished on approaching the apical region, but we observed very significant differences between values (Figure 4).

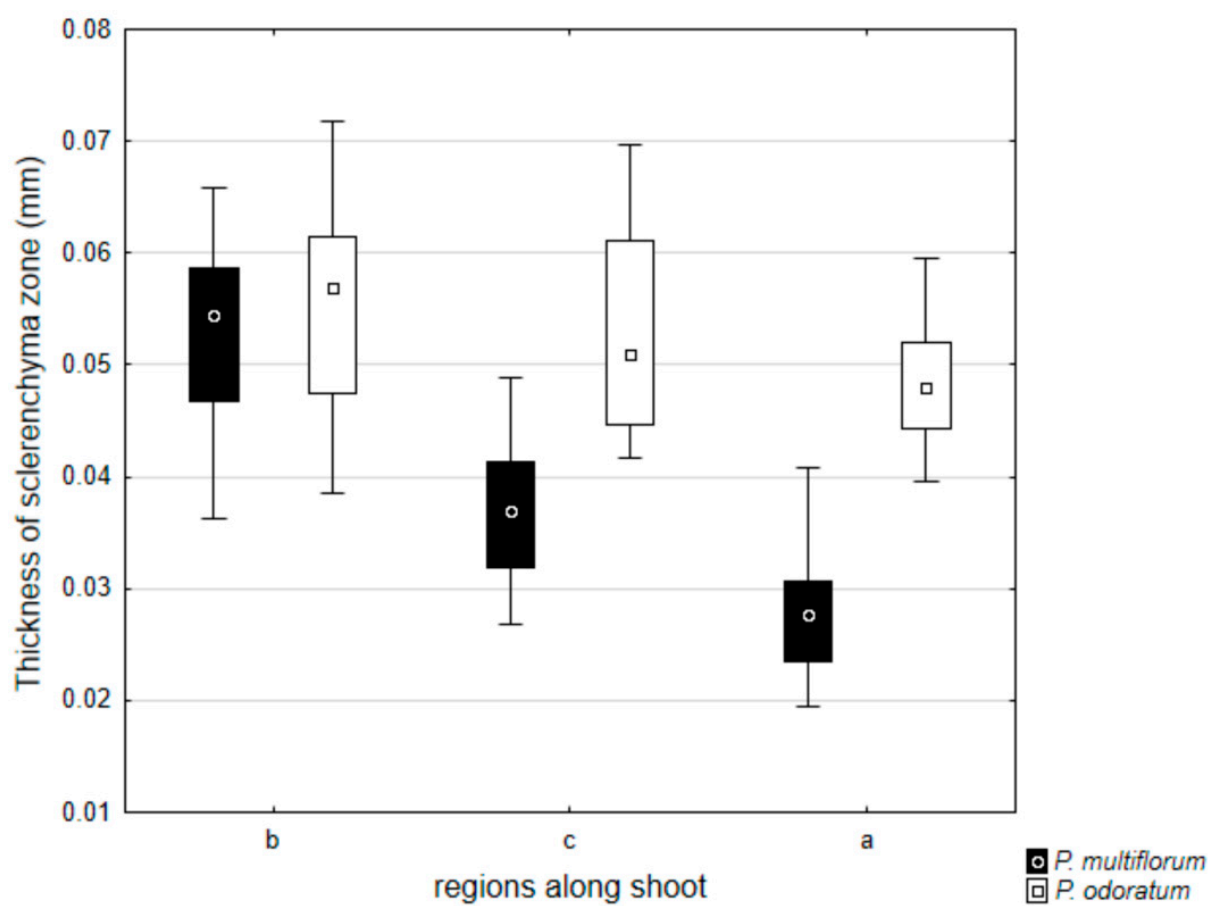

Figure 4. Thickness of sclerenchyma zone at basal (b), central (c) and apical (a) regions along shoot of both species. Significant differences are for central $(p<0.0001)$ and apical $(p<0.0000001)$ regions. 
Moreover, the species differed significantly with respect to the radius/diameter, thickness of the outer parenchyma zone and sclerenchyma zone relative to the overall length of their shoots (Table 2).

Table 2. Values of Student's $t$-test for the mean radius and thickness of the outer parenchyma zone and sclerenchyma zone for the entire length of the shoot of tested plants.

\begin{tabular}{ccccc}
\hline \multirow{2}{*}{ Variable } & \multicolumn{2}{c}{ Mean } & \multirow{t}{*}{$\boldsymbol{t}$-Value } & \multirow{2}{*}{$\boldsymbol{p}$-Value } \\
\cline { 2 - 3 } & P. o & P. $\mathbf{~}$ & & \\
\hline $\begin{array}{c}\text { Radius } \\
\begin{array}{c}\text { Thickness of outer } \\
\text { parenchyma zone }\end{array}\end{array}$ & 1.6416 & 1.4050 & 2.0269 & 0.0456 \\
$\begin{array}{c}\text { Thickness of sclerenchyma } \\
\text { zone }\end{array}$ & 0.1674 & 0.0969 & 13.0812 & 0.0000 \\
\hline P. o-P. odoratum; P. m—P. multiflorum. Means are expressed in $\mathrm{mm}, n=45$. & 0.0000
\end{tabular}

\subsection{Allometric Relationships}

Correlations between diameter (D) and length (L) of the shoot for each of the two species and for all three regions of the shoot (basal, central and apical) were very significant (Table 3, Figure 5). For P. multiflorum, values for $r$ were greater than for P. odoratum. For both species, values for $r$ were greater for the basal region than for the apical region of the shoot. Individuals of P. multiflorum had longer shoots, although these had smaller diameters.

Table 3. Values of Pearson's correlation coefficients $(r)$ between diameter (D) and length (L) of the shoot for the two species P. odoratum and P. multiflorum based on three regions of the shoot (basal, central and apical).

\begin{tabular}{cccc}
\hline & \multicolumn{3}{c}{$r$ D-L } \\
\cline { 2 - 4 } & Basal & Central & Apical \\
\hline P. odoratum & $0.7305^{* *}$ & $0.8555^{* * *}$ & $0.6224^{*}$ \\
P. multiflorum & $0.9626^{* * *}$ & $0.9152^{* * *}$ & $0.8511^{* * *}$ \\
\hline
\end{tabular}

Data transformed to natural logarithm. Asterisks denote the statistical significance of Pearson's correlation coefficient: ${ }^{* * *} p<0.001,{ }^{* *} p<0.01,{ }^{*} p<0.05, n=15$.

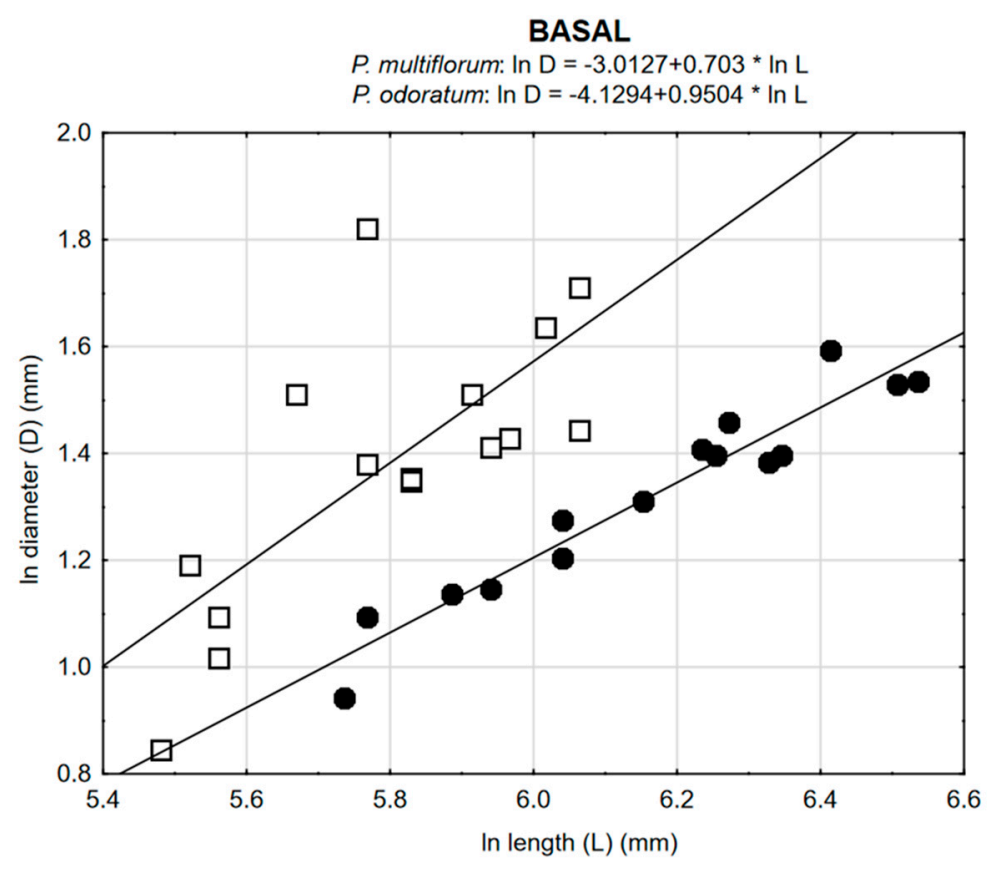

Figure 5. Cont. 
CENTRAL

P. multiflorum: $\ln \mathrm{D}=-2.3041+0.5564$ * $\ln \mathrm{L}$

P. odoratum: $\ln D=-4.2295+0.949 * \ln \mathrm{L}$

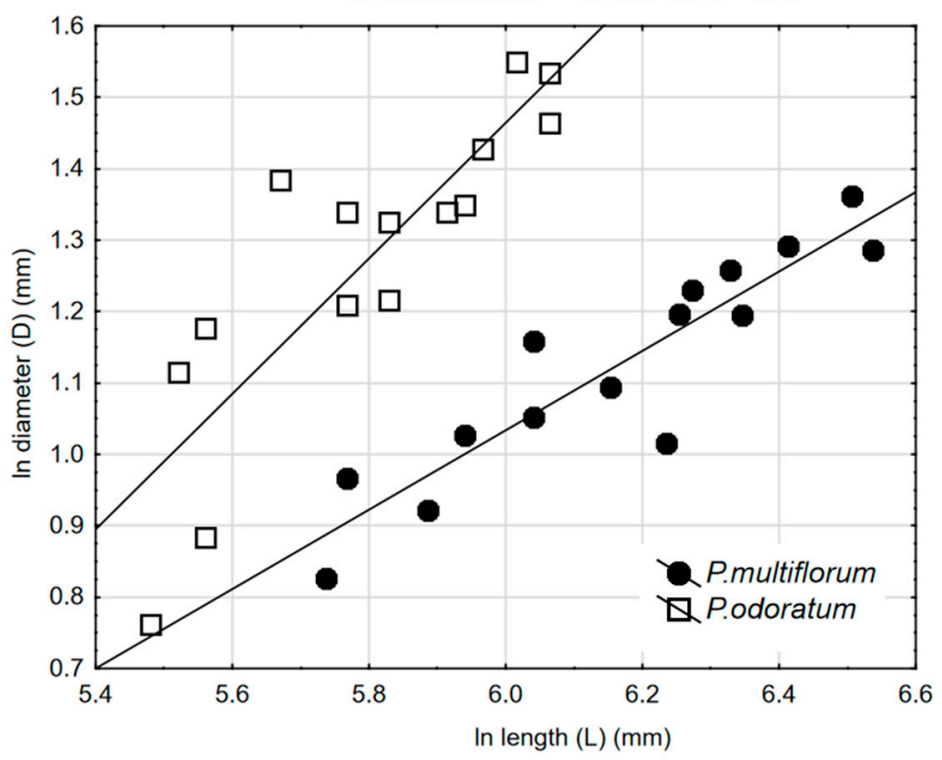

APICAL

P. multiflorum: $\ln \mathrm{D}=-2.5458+0.4786$ * $\ln \mathrm{L}$ P. odoratum: $\ln D=-1.9235+0.4587 * \ln \mathrm{L}$

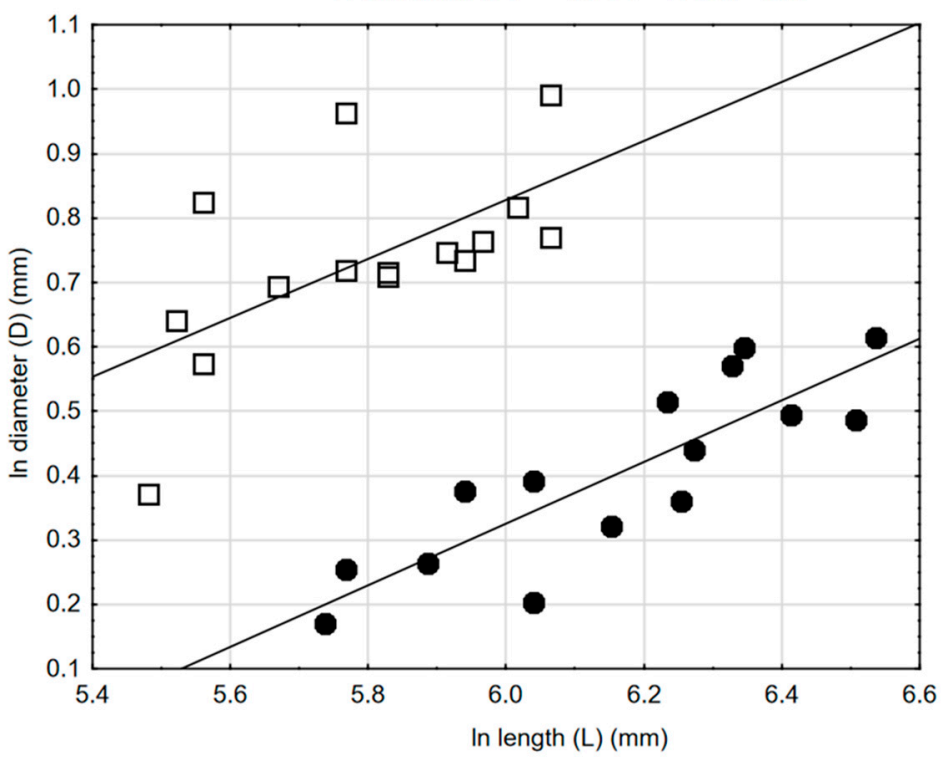

Figure 5. Relationships between diameter and length for all three regions of the shoot for the two species P. odoratum and P. multiflorum.

A relationship also existed between mass $(\mathrm{M})$ and length $(\mathrm{L})$ of the shoot (data ln-transformed). For both species, coefficients of correlation were similar: for P. multiflorum $r=0.6473$ and for P. odoratum $r=0.6757, p<0.01$ (Figure 6). Individuals of $P$. multiflorum were generally larger, with longer shoots and greater mass. 


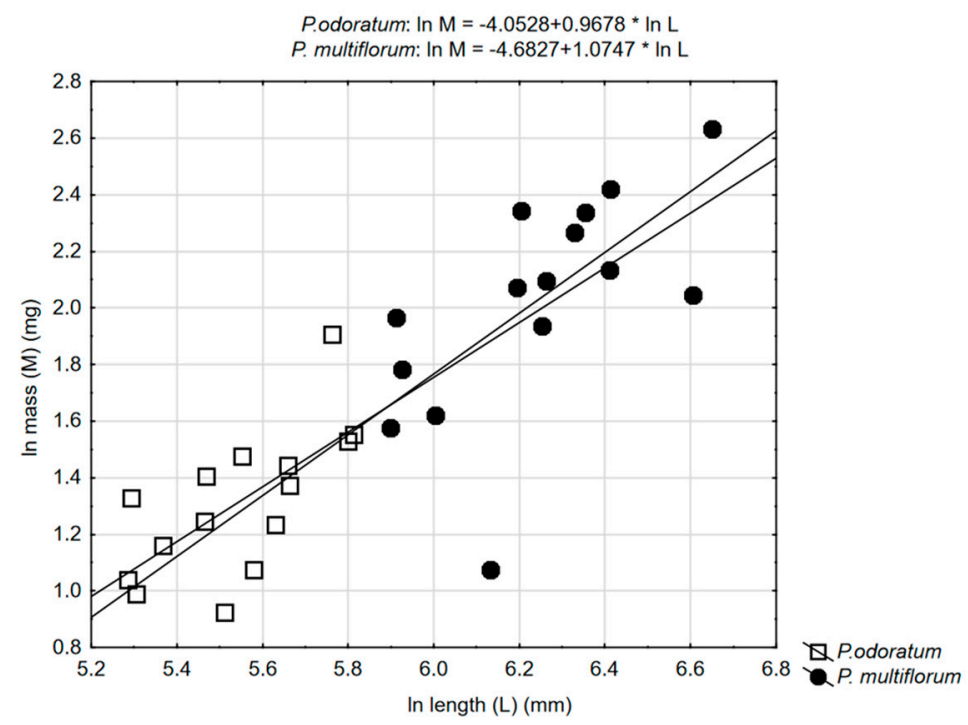

Figure 6. Relationships between mass and length of the shoot for the two species P. odoratum and P. multiflorum.

We also observed correlations between the thickness of the sclerenchyma zone (Ws) and that of the outer parenchyma zone (Wp) vs. shoot diameter (D), as well as shoot length (L), in both species (Table 4). Correlations were generally stronger for the basal part of the shoot than for the apical region, but this relationship was generally not very strong.

Table 4. Values of Pearson's correlation coefficients $(r)$ between the thickness of the sclerenchyma zone (Ws) and the thickness of the outer parenchyma cylinder (Wp) vs. shoot diameter (D) and shoot length (L) for P. odoratum and P. multiflorum based on three regions of the shoot (basal, central and apical).

\begin{tabular}{ccccc}
\hline & \multicolumn{4}{c}{ P. odoratum } \\
\cline { 2 - 5 } & Ws-D & Ws-L & Wp-D & Wp-L \\
\hline basal & $0.529657^{*}$ & $0.664209^{* *}$ & NS & $0.599483^{*}$ \\
central & NS & NS & NS \\
apical & NS & \multicolumn{4}{c}{$\boldsymbol{P . \text { multiflorum }}$} \\
\hline & Ws-D & Ws-L & Wp-D & Wp-L \\
\cline { 2 - 5 } & $0.816187^{* * *}$ & $0.799026^{* * *}$ & NS & NS \\
basal & NS & NS & NS & NS \\
central & $0.522822 *$ & $0.741862^{* *}$ & NS & apical
\end{tabular}

Data transformed to natural logarithm. Asterisks denote the statistical significance of Pearson's correlation coefficient: ${ }^{* * *} p<0.001,{ }^{* *} p<0.01,{ }^{*} p<0.05$, NS-non significant, $n=15$.

\section{Discussion}

The organization and spatial distribution of tissues in the shoot of two species of Polygonatum may support the thesis that these plants are adapted to be resistant to mechanical failure, since they are composed of a variety of cells whose walls (made of cellulose and lignin) differ in elasticity $[5,18]$. Comparison of the shoot structure of Polygonatum with the anatomy of grasses reveals a universal solution to certain structural problems (in particular those relating to mechanical support) common to both groups of plants. Fundamentally, the most common type of aerial shoot anatomy in monocots is based on the presence of a peripherally situated cylinder of sclerenchyma fibres. Hypodermal sclerenchyma is also very common in grass. This tissue is dead at maturity, with thick, lignified walls enclosing an empty lumen $[5,19]$. The distribution of this tissue provides increased support and rigidity and helps the plant withstand forces, such as wind. Centralized arrangement of mechanical 
tissues is also observed, especially in roots, as well as the shoots of submerged, aquatic angiosperms, both of which are subject to pulling strains [20]. A sclerotic sheath (a sheath of sclerenchymatous fibres surrounding the vascular bundles) may comprise the main stiffening element in many other monocots, such as palms [21]. It is stiffer by far than the surrounding parenchymatous ground tissue in which the vascular bundles are embedded [22-24]. It is also worth noting that the shoot of grasses is usually hollow e.g., the internodes of cereals. In other words, air occurs at the 'core' of grass shoots and this is the lightest and least expensive arrangement, both in terms of material and energy expenditure. Moreover, it permits longitudinal gaseous transport and is of particular value in certain marginal plants, where like the aerenchyma of true hydrophytes, it may allow the aeration of submerged organs. The arrangement of mechanical tissue, both peripherally and around each vascular bundle is considered optimal and in the case of grasses, provides excellent protection from mechanical failure (e.g., wilting), since the weight of plant per unit of shoot volume is greatly reduced. In describing the morphological and anatomical adaptation of grass shoots to mechanical stress, Frey [25] compared it with a fundamental rule of eastern fighting, namely, "flex to win". In contrast to grasses, the shoot core of Polygonatum is solid and parenchymatous, consisting of thin-walled parenchyma cells. Thin-walled tissues tend to possess lower elastic moduli than thick-walled tissues [5]. Nevertheless, they become increasingly important when the shoot is thick and the amount of sclerenchyma present small. Parenchyma may provide mechanical support hydrostatically by means of cell turgidity [5].

As previously mentioned, in order to be resistant to mechanical support, the shoot must be able to bend, but not break, and therefore it is necessary that the most rigid tissue is peripherally located. As a result, some sort of compromise must be reached between the distribution of mechanical and photosynthetic tissue. The question then arises: How do both species of Polygonatum resolve this anatomical conflict between the requirement for support and that for photosynthesis? One possible explanation in the case of P. multiflorum is that the turgor pressure of the inner parenchyma cells on the inside of the cylinder of sclerenchyma reinforces the shoot. As a result, these plants may grow taller and become more slender so as to absorb more solar energy for photosynthesis and other light-dependent processes. In the case of P. odoratum, the outer zone of photosynthetic cortical parenchyma is wider and therefore the mechanically resistant sclerenchyma is less peripheral in its distribution. As a consequence, the shoots of this species are shorter and have a greater diameter, allowing the plant to grow at greater light intensities and owing to the wider zone of chlorophyllous cortical parenchyma (outer parenchyma), photosynthesis is enhanced. It would also appear that in the case of Polygonatum the compromise between mechanical support and photosynthesis is subject to the environment, especially since light conditions have a particularly strong impact both on plant size and form $[26,27]$.

The behaviour of P. multiflorum may also be compared with the growth strategy of sapling trees. Young and quickly growing trees produce juvenile wood external to the pith [28]. The properties of juvenile wood are different from those of mature wood and the former is thought to be mechanically more resistant. Cells of juvenile wood tend to be shorter and have thinner walls. Therefore, juvenile wood is less dense than mature wood [29]. Young trees have slender stems that are more flexible than those of older trees, may grow rapidly towards the canopy and bend without breaking. It seems that the shoots of $P$. multiflorum, which are taller and have a smaller diameter, are better adapted to compete for light than those of P. odoratum (despite the fact that their mechanical tissue is represented by sclerenchyma and/or parenchyma cells, and that the pattern of biomass partitioning is intermediate to that typical of herbaceous plants and trees).

Allometric relations have frequently been reported for trees (in order to estimate their total biomass or root mass-parameters that are difficult to measure), but are less often reported for herbaceous plants, which are believed to be a result of natural selection processes and adaptive evolutionary changes [30-32]. Weiner and Thomas [16] suggested that the ability of plants to adapt to the environment modifies allometric relationships, especially in annual plants, and may depend on the prevailing growing conditions [33,34]. Jarzyna [35] investigated allometric relationships for competing 
and non-competing plants, discovering that those for competing plants were stronger. It is likely that in both P. odoratum and P. multiflorum, amongst others, the availability of light may be a crucial factor for explaining allometric relationships. These relationships are stronger in P. multiflorum, probably because this species grows in poorer light conditions (oak-hornbeam forest). In moderately humid deciduous forests, the percentage of sunlight reaching through the tree foliage to the herb and moss layer on the forest floor is less than $2 \%-5 \%$ [12]. Moreover, light reaches the forest floor mainly in the dormant season, while in the summer time, leaves of the canopy trees block the passage of light to the ground. Based on differences in tree crown morphology and the stand structure occupied by both investigated species of Polygonatum, it could be assumed that in a dense forest stand occupied by P. mutliflorum, less light penetrates through the canopy. Thus, with limited light availability in the understory, the taller P. multiflorum might invest more energy into its aboveground biomass i.e., its supporting shoot.

\section{Conclusions}

Our paper contributes towards a better understanding of the relationship that exists between plant structure and the environment, based on two contrasting species of Polygonatum (P. odoratum and P. multiflorum) growing on the forest floor that differ from each other in the shape of the shoot, as viewed in transverse section. We conclude that the spatial distribution of tissues in the shoots of the investigated species is typical of that found in self-supporting herbaceous plants. In P. multiflorum, the strong correlation between shoot diameter and length seems to be important to growth in shaded habitats.

Author Contributions: Conceptualization, M.T. and N.S.; Investigation and Methodology, M.T., N.S. and J.J.M.; Software, J.K. and I.J.; Writing-Review and Editing, M.T., I.J., J.J.M.

Funding: This research received no external funding.

Conflicts of Interest: The authors declare that there is no conflict of interest.

\section{References}

1. Reinhard, D.; Kuhlemeier, C. Plant architecture. EMBO Rep. 2002, 3, 846-851. [CrossRef] [PubMed]

2. Crook, M.J.; Ennos, A.R. Mechanical differences between free-standing and supported wheat plants, Triticum aestivum L. Ann. Bot. 1996, 77, 197-202. [CrossRef]

3. Gartner, B.L. Root biomechanics and whole plant allocation patterns: Responses of tomato to stem flexure. J. Exp. Bot. 1994, 45, 1647-1654. [CrossRef]

4. Crook, M.J.; Ennos, A.R.; Sellers, E.K. Structural development of the shoot and root systems of two winter wheat cultivars. J. Exp. Bot. 1994, 45, 857-863. [CrossRef]

5. Niklas, K.J. Plant allometry: The Scaling of Form and Process; University of Chicago Press: Chicago, IL, USA, 1994; ISBN 9780226580814.

6. Grime, J.P. Evidence for the existence of three primary strategies in plants and its relevance to ecological and evolutionary theory. Amer. Nat. 1977, 111, 1169-1194. [CrossRef]

7. Schmidt, W.; Weitemeier, M.; Holzapfel, C. Vegetation dynamics in canopy gaps of beech forest on limestone-The influence of the light gradient on species richness. Verh. Ges. Ökol. 1996, 25, 253-260.

8. Elemans, M. Light, nutirents and the growth of herbaceous forest species. Acta Oecol. 2004, 26, $197-202$. [CrossRef]

9. Tinya, F.; Márialigeti, S.; Király, B.; Németh, B.; Ódor, P. The effect of light conditions on herbs, bryophytes and seedlings of temperate mixed forests in Örség, Western Hungary. Plant Ecol. 2009, 204, 69-81. [CrossRef]

10. Chazdon, R.L.; Pearcy, R.W. The importance of sunflecks for forest understory plants. BioScience 1991, 41, 760-766. [CrossRef]

11. Kitajima, K.; Mulkey, S.S.; Wright, J. Variation in crown light utilization characteristics among tropical canopy trees. Ann. Bot. 2005, 95, 535-547. [CrossRef]

12. Núnements, Ü. A review of light interception in plant stands from leaf to canopy in different plant functional types and in species with varying shade tolerance. Ecol. Res. 2010, 25, 693-714. [CrossRef]

13. Obmiński, Z. Ekologia Lasu; Państwowe Wydawnictwo Naukowe: Warszawa, Poland, 1977; pp. 260-268. 
14. Gärtner, H.; Schweingruber, F.H. Microscopic Preparation Techniques for Plant Stem Analysis; Kessel Publishing House: Remagen, Germany, 2013; ISBN 978-3-941300-76-7.

15. Broda, B. Metody Histochemii Roślinnej; Państwowy Zakład Wydawnictw Lekarskich: Warszawa, Poland, 1971.

16. Weiner, J.; Thomas, S.C. Competition and allometry in three species of annual plants. Ecology 1992, 73, 648-656. [CrossRef]

17. Poorter, H.; Jagodziński, A.M.; Ruiz-Peinado, R.P.; Kuyah, S.; Luo, Y.; Oleksyn, J.; Usoltsev, V.A.; Buckley, T.N.; Reich, T.N.; Reich, P.B.; et al. Howe does biomass distribution change with size and differ among species? An analysis for 1200 plant species from five country. New Phytol. 2015, 208, 736-749. [CrossRef] [PubMed]

18. Vincent, J.F.V. The mechanical design of grass. J. Mater. Sci. 1982, 17, 856-860. [CrossRef]

19. Goodman, A.M. Mechanical adaptations of Cleavers (Gallium aparine). Ann. Bot. 2005, 95, 475-480. [CrossRef] [PubMed]

20. Koehl, M.A.R.; Wainwright, S.A. Mechanical adaptation of a giant kelp. Limnol. Oceanogr. 1997, 22, $1067-1071$. [CrossRef]

21. Rüggeberg, M.; Bugert, I.; Speck, T. Structural and mechanical design of tissue interfaces in the giant reed Arundo donax. J. R. Soc. Interface 2010, 7, 499-506. [CrossRef]

22. Rich, P.M. Mechanical structure of the stem of arborescent palms. Bot. Gaz. 1987, 148, 42-50. [CrossRef]

23. Tomlinson, P.B. The Structural Biology of Palms; Clarendon Press: Oxford, UK, 1990; ISBN 10: 019854572X.

24. Spatz, H.C.; Beismann, H.; Brüchert, F.; Emanns, A.; Speck, T. Biomechanics of the giant reed Arundo donax. Philos. Trans. R. Soc. Lond. 1997, 352, 1-10. [CrossRef]

25. Frey, L. Trawy niezwyciężone. Łąkarstwo W Pol. 2000, 3, 9-20.

26. Winer, J.; Bernston, G.M.; Thomas, S.C. Competition and growth form in a woodland annual. J. Ecol. 1990, 78, 459-469. [CrossRef]

27. Watari, R.; Nagashima, H.; Hirose, T. Stem extension and mechanical stability of Xantium canadense grown in an open or in dense stand. Ann. Bot. 2014, 114, 179-190. [CrossRef] [PubMed]

28. Zobel, B.J.; Sprague, J.R. Juvenille Wood in Forest Trees; Springer-Verlag: Berlin, Germany, 1998; ISBN 978-3-642-72126-7.

29. Plomion, C.; Leprovost, G.; Stokes, A. Wood formation in trees. Plant Physiol. 2001, 127, 1513-1517. [CrossRef] [PubMed]

30. Niklas, K.J. Plant height and the properties of some herbaceous stems. Ann. Bot. 1995, 75, 133-142. [CrossRef]

31. Castelan-Estrada, M.; Vivin, P.; Gaudillére, J.P. Allometric relationships estimate seasonal above-ground vegetative and reproductive biomass of Vitis vinifera L. Ann. Bot. 2002, 89, 401-408. [CrossRef]

32. Enquist, B.J. Universal scaling in tree and vascular plant allometry toward a general quantitative theory linking plant form and function from cells to ecosystems. Tree Physiol. 2002, 22, 1045-1064. [CrossRef]

33. Prior, S.A.; Rogers, H.H. Soybean growth response to water supply. J. Plant Nutr. 1995, 18, 617-636. [CrossRef]

34. Wang, P.; Weiner, J.; Cahill, J.F.; Zhou, D.W.; Bian, H.F.; Song, Y.T.; Sheng, L.X. Shoot competition, root competition and reproductive allocation in Chenopodium accuminatum. J. Ecol. 2014, 102, 1688-1696. [CrossRef]

35. Jarzyna, I. Plant morphology and allometric relationships in competing and non-competing plants of Tagetes patula L. Acta Soc. Bot. Pol. 2002, 71, 149-154. [CrossRef]

(C) 2018 by the authors. Licensee MDPI, Basel, Switzerland. This article is an open access article distributed under the terms and conditions of the Creative Commons Attribution (CC BY) license (http:/ / creativecommons.org/licenses/by/4.0/). 